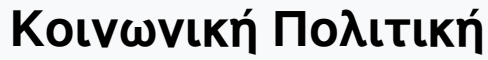

Tón. 8 (2017)

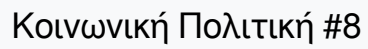

\section{EE \\ K П HELENIC SOCLLL POUCY ASSOCLATIOW \\ Koıvwvıkń Поกีıเıkń}

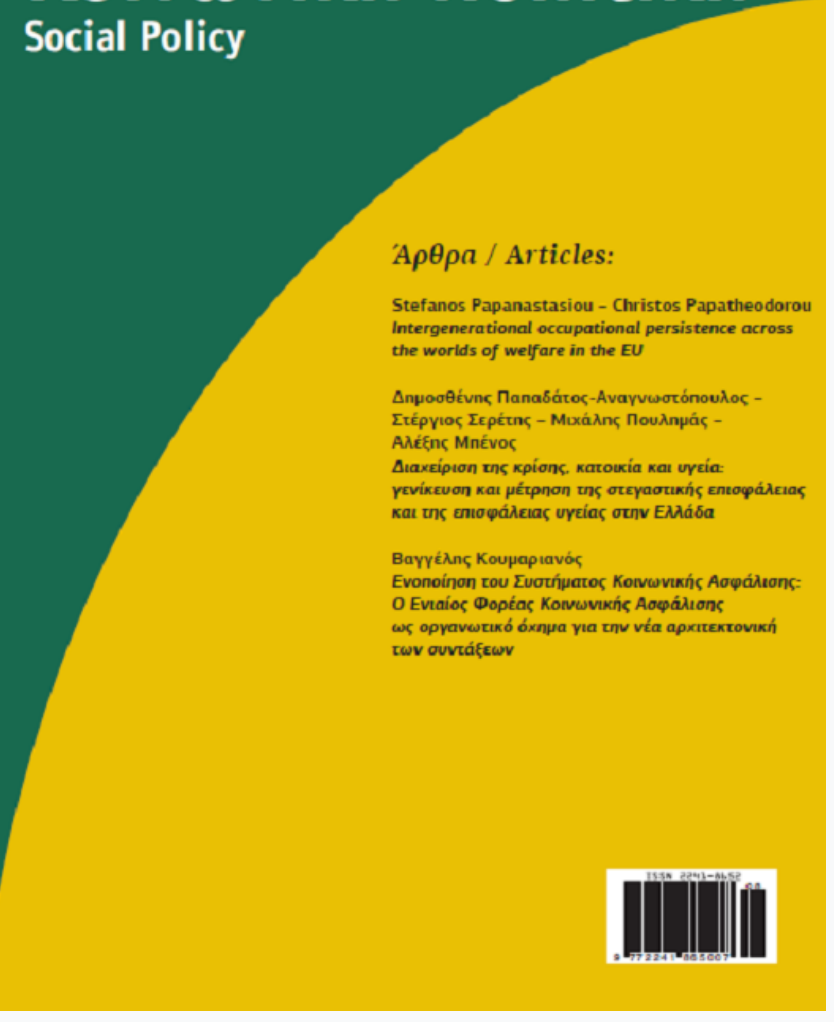

Intergenerational Occupational Persistence across the Worlds of Welfare in the EU

Stefanos Papanastasiou, Christos Papatheodorou

doi: $10.12681 / \mathrm{sp} .14602$

Copyright (C) 2017, Stefanos Papanastasiou, Christos Papatheodorou

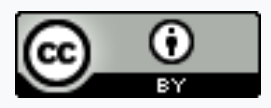

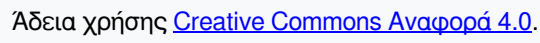

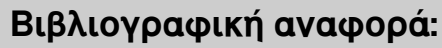

Papanastasiou, S., \& Papatheodorou, C. (2017). Intergenerational Occupational Persistence across the Worlds of

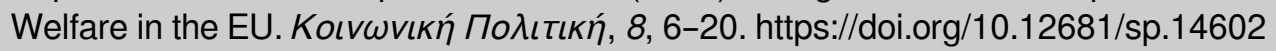




\title{
Intergenerational occupational persistence across the worlds of welfare in the EU
}

\author{
Stefanos Papanastasiou \\ PhD Researcher, Democritus University of Thrace

\section{Christos Papatheodorou} \\ Professor of Social Policy, Panteion University of Social and Political Sciences
}

\section{Abstract}

This paper investigates the intergenerational persistence in the occupational status across the four EU welfare regimes. Utilizing EU-SILC 2005 microdata through multinomial logit models, the paper brings to the forefront the performance of different social protection systems vis-à-vis intergenerational occupational persistence. The countries of the Liberal welfare regime exhibit the highest persistence and those of the Social-democratic welfare regime the lowest one, while the countries of the Conservative-Corporatist and the South-European welfare cluster place themselves somewhere in between. These findings imply a success-story in intercepting the intergenerational persistence in occupations by the regulatory and redistributive mechanisms of the Social-democratic welfare state.

Key-words: intergenerational mobility, occupational mobility, occupational status, welfare regimes, $E U$,

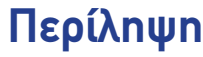

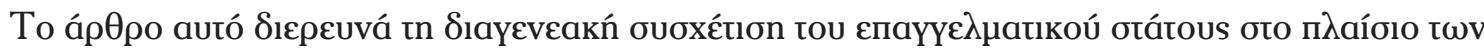

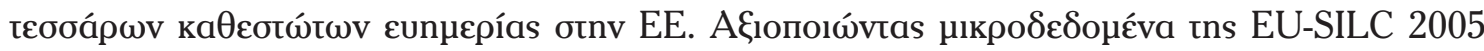

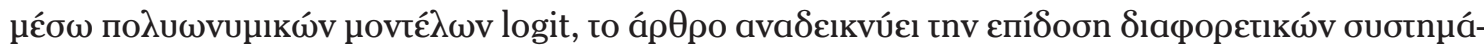

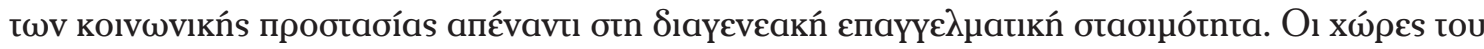

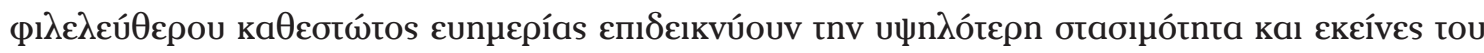

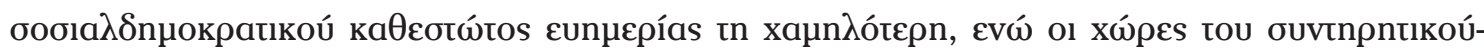

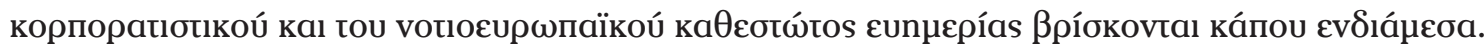




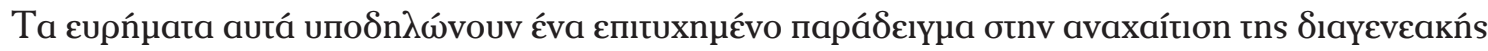

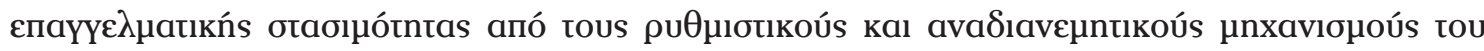

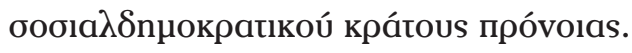

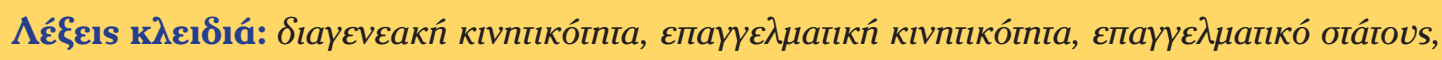

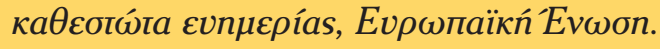

\section{Introduction}

Intergenerational social mobility has been a central topic within empirical studies of social stratification. It can take two forms: absolute and relative (Goldthorpe, 2012; Torche, 2013). Absolute mobility refers to changes in the distribution of socioeconomic attainments among parents and children because of structural changes, whereas relative mobility is also known as social fluidity and refers to the probability of individuals from low social status families to climb up the social ladder compared to the probability of individuals from higher social status families.

The leading way to measure intergenerational social mobility is through the correlation of the parent's position with the children's one, when they become adults, along the socioeconomic ladder. The empirical investigation of this correlation in various dimensions (e.g. income, wage, occupation, education, health or even values and attitudes) facilitates the understanding of the causal factors of social fluidity and enhances the policy interventions in this field (see d' Addio, 2007 for a meta-analysis).

This paper examines the persistence in occupational attainments across generations from an empirical point of view. This is pursued by utilizing the EU-SILC 2005 intergenerational dataset, which is preferred over the similar 2011 one, mainly because it has available intergenerational weights for all the countries under consideration. Those countries are the old EU-15 member-states apart from Luxembourg, which is not considered representative because of its extremely small population and high living standards.

The EU-14 countries are grouped into four clusters following Esping-Andersen's (1990) typology and the relevant academic debate on the welfare regime of the south European countries (Liebfried, 1993; Ferrera, 2000; Papatheodorou \& Petmesidou, 2004, 2005): Socialdemocratic (Sweden, Denmark, Finland, Netherlands), Conservative-Corporatist (Germany, France, Austria, Belgium), Liberal (United Kingdom, Ireland) and South-European (Italy, Spain, Greece, Portugal). What is more, the welfare clusters are rescaled to get comparable estimates by assigning a different weighting factor to each one of them after having taken cluster and country sample representativeness into account.

The paper examines the correlation in the occupational status among fathers and sons from a welfare regime perspective. A distinctive feature of the analysis is the incorporation of unconditional country and cohort fixed effects as well as of education as intervening variable in the association between origin and destination. The methodology of this analysis relies on multi- 
nomial logit models, because the polytomous occupation variable is assumed to be of nominal nature. This variable is merged into three categories based on Wald tests and the International Standard Classification of Occupations.

The paper is structured as follows: the next section summarizes the theoretical debate and main empirical findings on intergenerational persistence. The third section provides information on the dataset and the methodology of the analysis and offers an empirical exploration of the intergenerational persistence in occupational attainments across the EU welfare clusters. The last section wraps up the main empirical findings and assesses the policy implications of intergenerational occupational persistence.

\section{Theoretical debate}

The causal factors of intergenerational persistence have been characterized as "Gordian knot" (Esping-Andersen, 2004) and as "black box" (Bowels \& Gintis, 2002) to indicate the complexity of this matter. The intergenerational persistence can occur due to several factors, such as the concentration of productive activities in certain regions along time (Krugman, 1991; Fujita et al, 1999) or the group effects arising from social interactions (Shelling, 1971; Durlauf, 2006) or the family income effect on offspring's socioeconomic attainments (Becker \& Tomes, 1979; Loury, 1981; Banerjee \& Newman, 1993; Galor \& Zeira, 1993; Eckstein \& Zilcha, 1994; Mookherjee \& Ray, 2003).

Most studies agree that the parental lack of income is basic determinant of children's diminishing mobility prospects through various processes. The dominant approach emphasizes the parental underinvestment in children's human capital due to credit constraints in the economy (Becker \& Tomes, 1979, 1986). Another approach points out the correlation of parental lack of income with other parental socioeconomic disadvantages (e.g. bad health, low education, limited social capital, insufficient cultural capital, etc.), which are likely to be passed on to children and reduce their mobility prospects (Haveman et al, 1991; Corcoran, 1995; Corcoran \& Adams, 1997; Mayer, 1997; Boggess \& Corcoran, 1999). Moreover, other researchers argue that parental poverty leads to intergenerational persistence among children by increasing the stress levels of parents and, thus, affecting the nurturing process (Mayer, 1997).

A distinct group of studies focuses on cultural and behavioural factors to explain the intergenerational persistence in socioeconomic attainments among poor people. Those studies draw upon two assumptions: the one is the "culture of poverty" and the other the "culture of welfare dependency" (Lewis, 1965, 1969; Mead, 1986, 1992; Murray, 1984). By and large, it is maintained that the poor are not inclined to cash in on the opportunities arising in life, because they absorb the values of the "culture of poverty" or of the "culture of welfare dependency". However, the above-mentioned studies have seriously been criticized, as they tend to blame the poor without even mentioning the socioeconomic system and the dominant ideology or culture, which not only cause poverty traps, but also hinder the escape from them (e.g. joblessness or in-work poverty). 
Other approaches place emphasis on biological factors, such as intelligence, to account for individual differences in socioeconomic attainments (Herrnstein \& Murray, 1994; Bond \& Saunders, 1999; Saunders, 1996, 1997, 2002; Strenze, 2007). Similarly, a group of studies stresses the importance of non-cognitive abilities or personality traits as explanatory factors of socioeconomic attainments (e.g. self-esteem, work-ethics, etc.) (Heckman \& Rubinstein, 2001, Carneiro \& Heckman, 2003, Heckman et al, 2006). A main problem with these approaches is that they tend to neglect confounding factors playing more crucial role than IQ or temperament (such as the family of origin's assets). Besides, measuring IQ is a rather arbitrary process that has been questioned over its preciseness and validity (Fisher et al, 1996; Breen \& Goldthorpe, 1999, 2001).

From an empirical point of view, the available studies indicate that the occupational status of children tends to reflect the one of parents. A meta-analysis carried out by Erikson and Goldthorpe (2002) finds out a correlation in the occupational status among parents and children (and especially among fathers and sons) in all developed countries. Moreover, another meta-analysis finds out substantial variation in the magnitude of this correlation in the EU, as the Nordic countries exhibit a low one, whereas Germany, France and Italy display a high one (d' Addio, 2007).

The variability in intergenerational occupational mobility is largely attributed to the different institutional settings that each EU member-state has developed (i.e. labor market, economy, social protection, tax system, education, healthcare, childcare, etc.). By contrast, focusing on individual factors to explain intergenerational persistence in occupational attainments is irrelevant to cross-country comparisons. Even the influence of the family of origin on children's future outcomes cannot be explained without reference to broader societal structures and institutions.

Nevertheless, investigating the impact of institutional factors on intergenerational persistence is still at an embryonic stage. This is due to the lack of relevant data and indicators as well as the difficulty to associate the micro-level with the macro-level. Among the few empirical studies carried out so far on that matter, those by Causa et al (2009) and Causa and Johanson (2009) find out a negative relationship between intergenerational persistence and equitable policies in the OECD countries. Moreover, Papanastasiou et al (2016), Papatheodorou \& Papanastasiou (2010) and Papanastasiou and Papatheodorou (2010) assess the impact of the social protection systems on intergenerational persistence in a highly indirect manner and capture a pattern in mobility outcomes based on distinct and longstanding welfare regimes in the EU.

\section{Empirical analysis}

The empirical analysis utilizes microdata from the intergenerational module of EU-SILC 2005. This dataset contains retrospective information on the parental background of the respondents when they were 14-16 years of age. The most relevant information refers to the occupational 
status of parents and children based on the classification system ISCO- 88 encompassing ten broad occupational categories. The occupation variable is merged into three categories to accommodate the empirical analysis. Adjusting the scheme proposed by Maitre and Whelan (2008), the three categories are:

- Higher skilled non-manual (i.e. managerial, scientific and technical occupations)

- Lower skilled non-manual (i.e. clerical workers and salespeople)

- Skilled/unskilled manual (i.e. farmers, fishermen, craftsmen, machine operators/ assemblers and unskilled workers).

Analysing the relationship of fathers' and sons' occupations by welfare regime, it appears that father's occupation affects son's occupation in all regimes. In other words, sons whose fathers had manual occupation are more likely to face downward occupational mobility than sons whose fathers had non-manual occupation (Figure 1). Similar differences in son's occupational attainments appear between those with a father in lower and in higher skilled non-manual occupation.

\section{Figure 1: Father's and son's occupation by welfare regimes}

\section{A. Social-democratic}

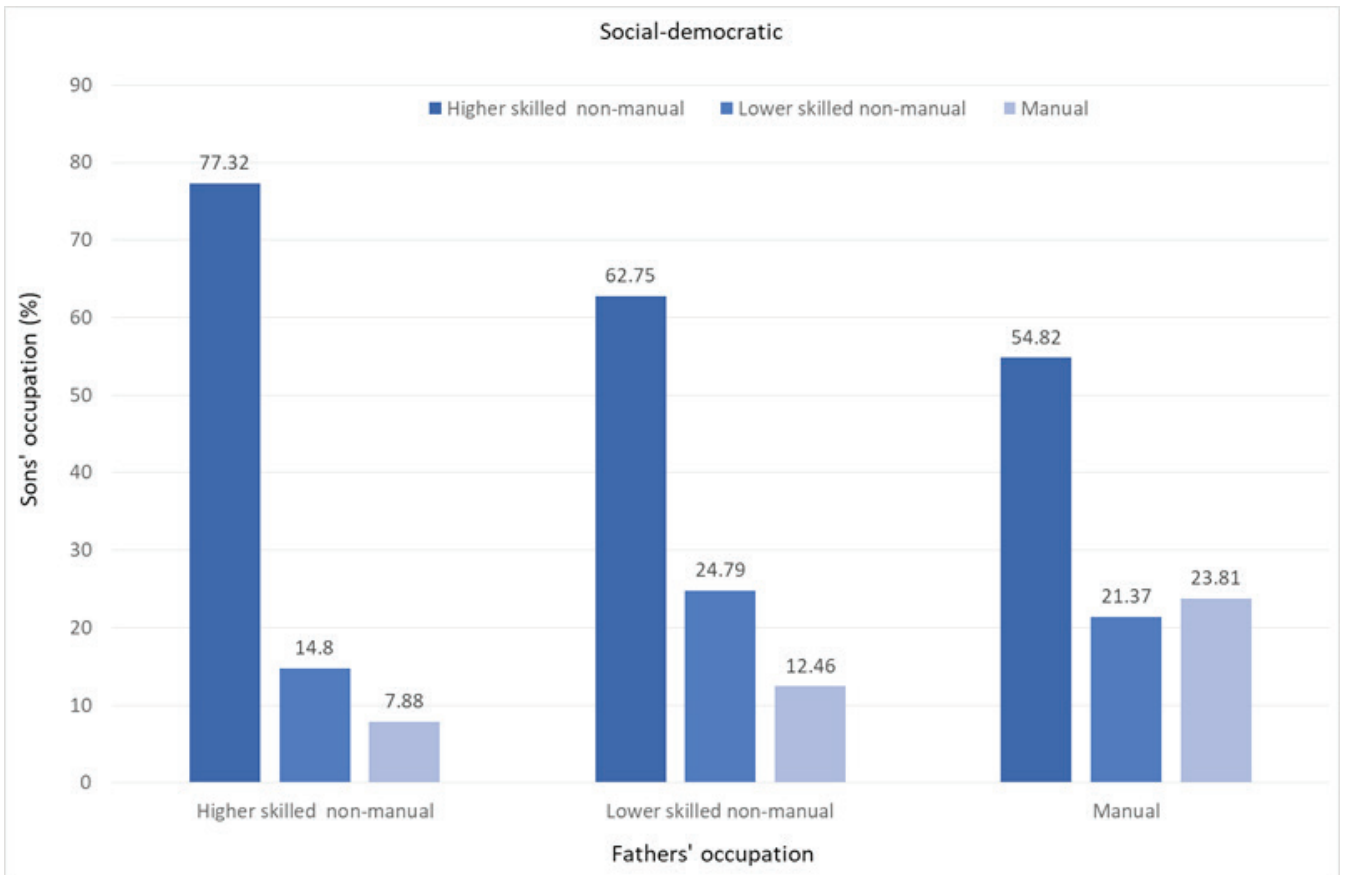




\section{B. Liberal}

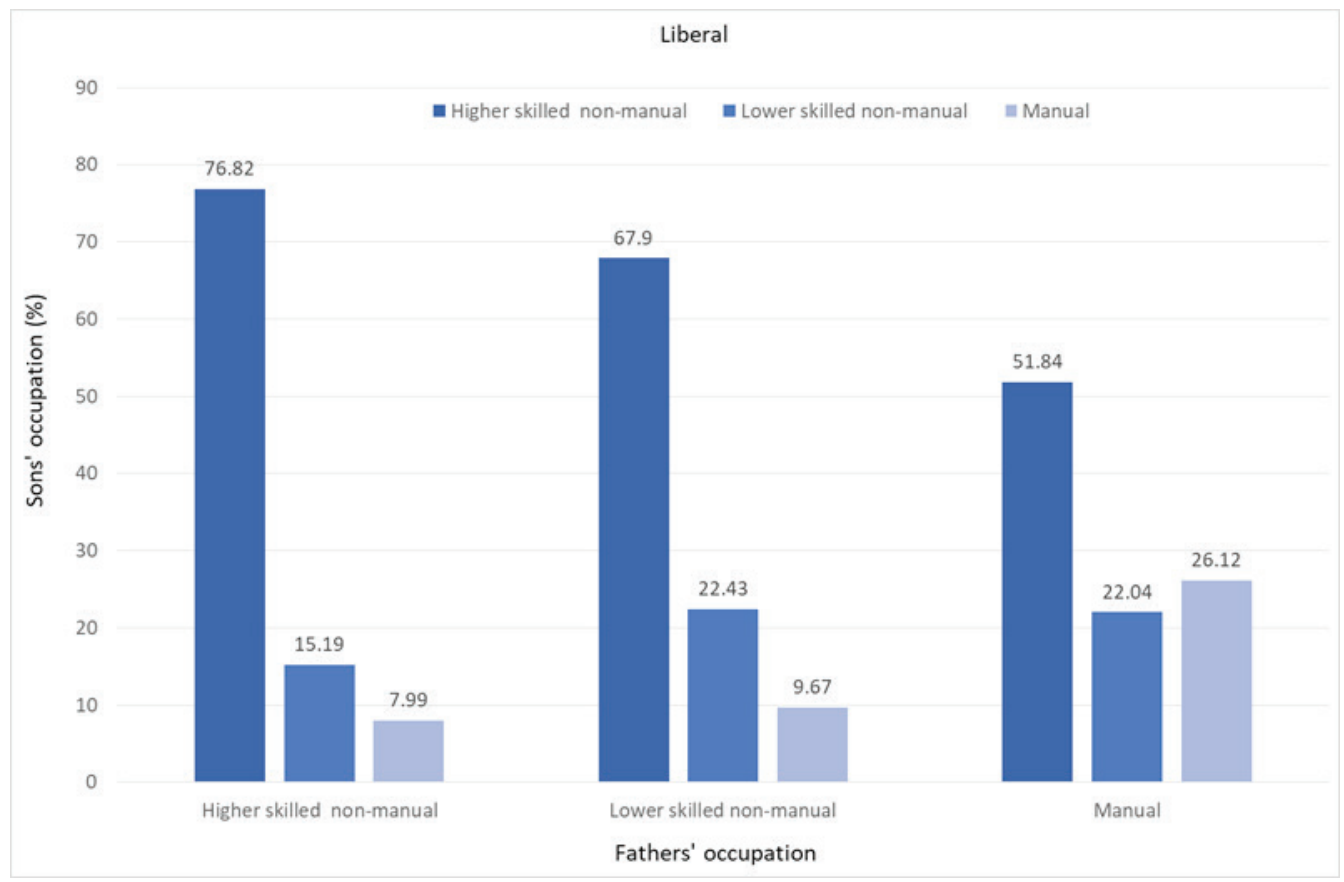

\section{Conservative-Corporatist}

Conservative-Corporatist

90

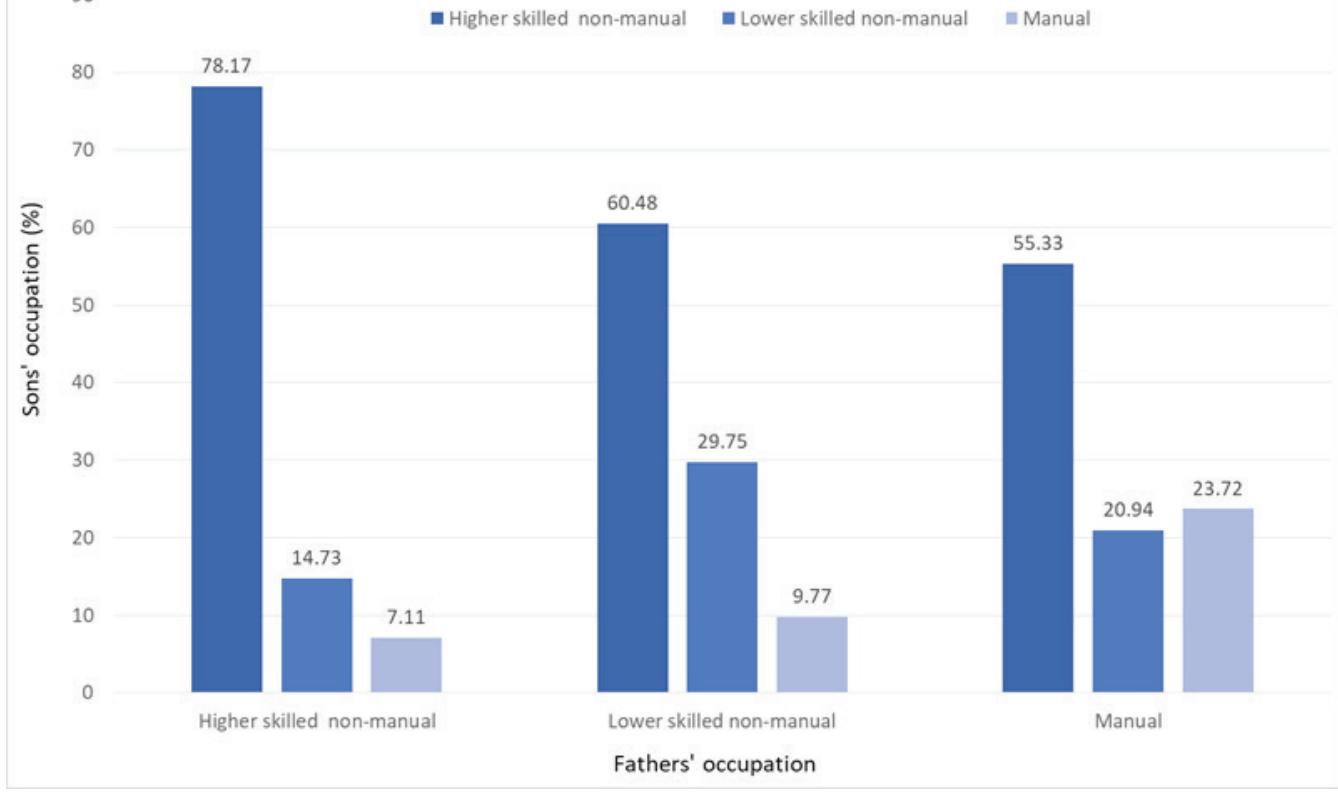




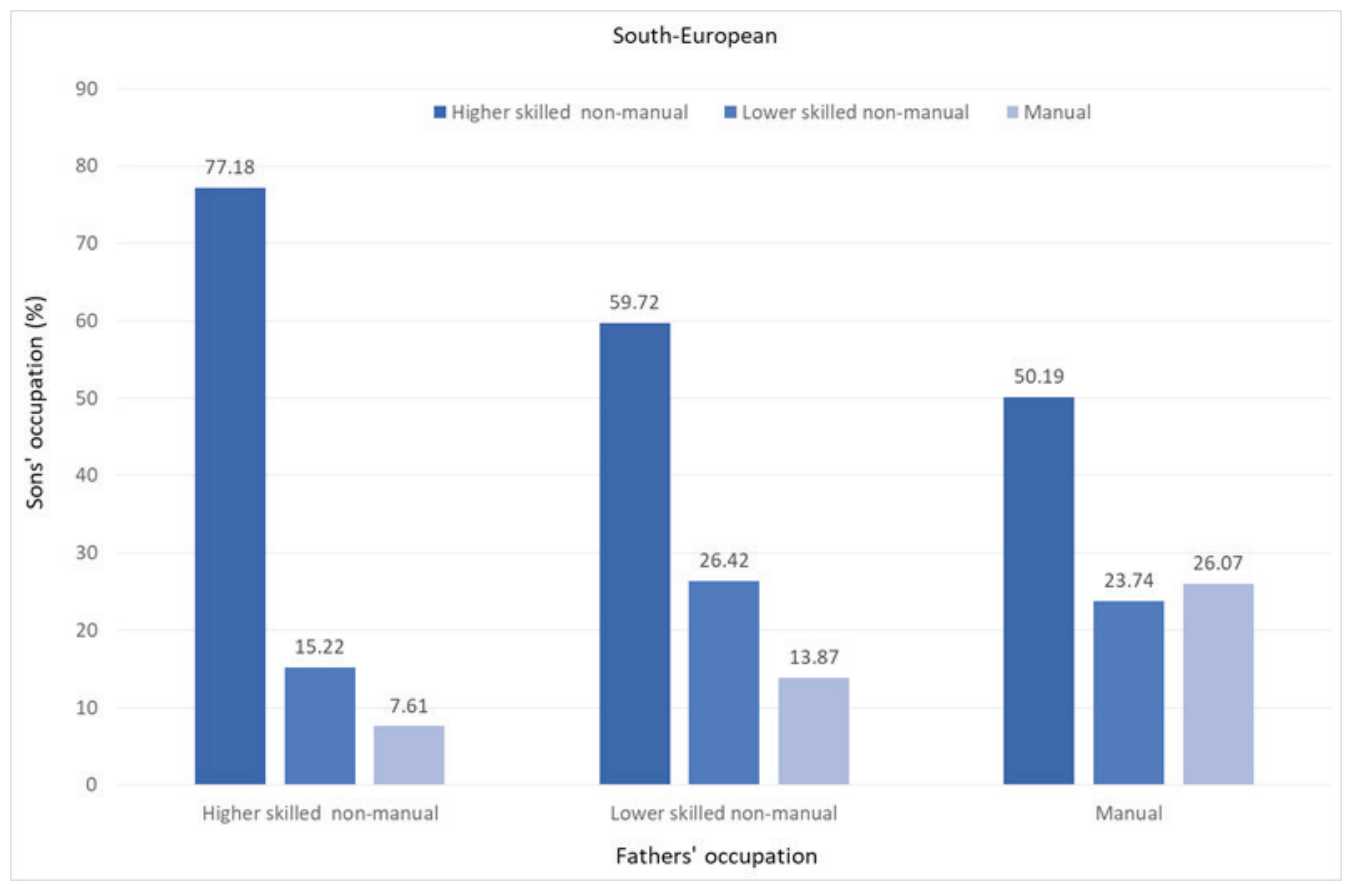

Source: Elaboration of microdata from EU-SILC 2005 UDB.

The empirical analysis incorporates unconditional country and cohort fixed effects by including dummy variables for countries and age. The countries under study comprise the old EU member-states expect Luxembourg, which is not considered because of its small population and high living standards. Those countries are grouped into four welfare regimes (Conservative-Corporatist, Liberal, Social-democratic and South-European), which are further rescaled by taking regime and country sample representativeness into account to get more reliable estimates.

Moreover, the analysis controls for education as mediating variable with categories $1=$ low, $2=$ medium and $3=$ high, as it is highly correlated with occupation. The methodology of the analysis is based on multinomial logistic regression, since the polytomous occupation variable is considered nominal one. The analysis focuses on pairs of fathers and sons, because only the statistical models on men display positive response to robustness checks. These models have been adjusted with the available intergenerational cross-sectional weight in the EU-SILC 2005. In fact, that was the reason why the EU-SILC 2005 dataset was chosen instead of the similar 2011 one in which the intergenerational weight is missing for some countries.

Cross-tabulating the occupations of fathers and sons across the EU welfare regimes shows that sons from low parental background are more likely to face downward occupational mobility than sons from higher parental background. Moreover, a bottom-to-top mobility (or persistence) index is calculated to provide an estimate of the strength of the association among the two variables. This index measures how likely it is for sons from manual parental background 
to attain non-manual occupations compared to sons from non-manual parental background. It appears that the association between the fathers' and sons' occupations is stronger in the countries of the Liberal welfare regime and weaker in those of the Social-democratic welfare regime, while the countries of the Conservative-Corporatist and the South-European regime stand in-between.

Table 1: The association of fathers' and sons' occupations in the EU welfare clusters

\begin{tabular}{|c|c|c|c|c|c|}
\hline \multirow{4}{*}{$\begin{array}{c}\text { Conservative- } \\
\text { Corporatist }\end{array}$} & Occupation & $\begin{array}{l}\text { Higher skilled } \\
\text { non-manual } \\
\text { (father) }\end{array}$ & $\begin{array}{l}\text { Lower skilled } \\
\text { non-manual } \\
\text { (father) }\end{array}$ & $\begin{array}{l}\text { Skilled/unskilled } \\
\text { manual } \\
\text { (father) }\end{array}$ & $\begin{array}{l}\text { Bottom-to-top } \\
\text { mobility index }\end{array}$ \\
\hline & $\begin{array}{l}\text { Higher skilled } \\
\text { non-manual } \\
\text { (son) }\end{array}$ & 40.95 & 16.46 & 42.59 & \multirow{3}{*}{0.54} \\
\hline & $\begin{array}{l}\text { Lower skilled } \\
\text { non-manual } \\
\text { (son) }\end{array}$ & 20.89 & 19.75 & 59.36 & \\
\hline & $\begin{array}{l}\text { Skilled/un- } \\
\text { skilled manual } \\
\text { (son) }\end{array}$ & 11.91 & 8.79 & 79.3 & \\
\hline & & \multicolumn{2}{|c|}{$\mathbf{N}$} & \multicolumn{2}{|c|}{6844} \\
\hline \multirow{4}{*}{ Liberal } & Occupation & $\begin{array}{l}\text { Higher skilled } \\
\text { non-manual } \\
\text { (father) }\end{array}$ & $\begin{array}{l}\text { Lower skilled } \\
\text { non-manual } \\
\text { (father) }\end{array}$ & $\begin{array}{l}\text { Skilled/unskilled } \\
\text { manual } \\
\text { (father) }\end{array}$ & $\begin{array}{l}\text { Bottom-to-top } \\
\text { mobility index }\end{array}$ \\
\hline & $\begin{array}{l}\text { Higher skilled } \\
\text { non-manual } \\
\text { (son) }\end{array}$ & 39.76 & 12.72 & 47.52 & \multirow{3}{*}{0.44} \\
\hline & $\begin{array}{l}\text { Lower skilled } \\
\text { non-manual } \\
\text { (son) }\end{array}$ & 21.73 & 17.73 & 60.54 & \\
\hline & $\begin{array}{l}\text { Skilled/un- } \\
\text { skilled manual } \\
\text { (son) }\end{array}$ & 10.19 & 7.5 & 82.31 & \\
\hline & & \multicolumn{2}{|c|}{$\mathbf{N}$} & \multicolumn{2}{|c|}{4130} \\
\hline
\end{tabular}




\begin{tabular}{|c|c|c|c|c|c|}
\hline \multirow{4}{*}{$\begin{array}{c}\text { Social- } \\
\text { democratic }\end{array}$} & Occupation & $\begin{array}{l}\text { Higher skilled } \\
\text { non-manual } \\
\text { (father) }\end{array}$ & $\begin{array}{l}\text { Lower skilled } \\
\text { non-manual } \\
\text { (father) }\end{array}$ & $\begin{array}{l}\text { Skilled/unskilled } \\
\text { manual } \\
\text { (father) }\end{array}$ & $\begin{array}{l}\text { Bottom-to-top } \\
\text { mobility index }\end{array}$ \\
\hline & $\begin{array}{l}\text { Higher skilled } \\
\text { non-manual } \\
\text { (son) }\end{array}$ & 42.11 & 13.57 & 44.32 & \multirow{3}{*}{0.58} \\
\hline & $\begin{array}{l}\text { Lower skilled } \\
\text { non-manual } \\
\text { (son) }\end{array}$ & 22.73 & 19.76 & 57.51 & \\
\hline & $\begin{array}{l}\text { Skilled/un- } \\
\text { skilled manual } \\
\text { (son) }\end{array}$ & 13.77 & 8.09 & 78.14 & \\
\hline & & \multicolumn{2}{|c|}{ N } & \multicolumn{2}{|c|}{7139} \\
\hline \multirow{4}{*}{$\begin{array}{l}\text { South- } \\
\text { European }\end{array}$} & Occupation & $\begin{array}{l}\text { Higher skilled } \\
\text { non-manual } \\
\text { (father) }\end{array}$ & $\begin{array}{l}\text { Lower skilled } \\
\text { non-manual } \\
\text { (father) }\end{array}$ & $\begin{array}{l}\text { Skilled/unskilled } \\
\text { manual } \\
\text { (father) }\end{array}$ & $\begin{array}{l}\text { Bottom-to-top } \\
\text { mobility index }\end{array}$ \\
\hline & $\begin{array}{l}\text { Higher skilled } \\
\text { non-manual } \\
\text { (son) }\end{array}$ & 39.06 & 13.88 & 47.07 & \multirow{3}{*}{0.50} \\
\hline & $\begin{array}{l}\text { Lower skilled } \\
\text { non-manual } \\
\text { (son) }\end{array}$ & 25.7 & 19.1 & 55.2 & \\
\hline & $\begin{array}{l}\text { Skilled/un- } \\
\text { skilled manual } \\
\text { (son) }\end{array}$ & 11.18 & 7.25 & 81.57 & \\
\hline & & \multicolumn{2}{|c|}{$\mathbf{N}$} & \multicolumn{2}{|c|}{11599} \\
\hline
\end{tabular}

Source: Elaboration of microdata from EU-SILC 2005 UDB.

Furthermore, the multinomial logit models used in the analysis have been adjusted to comply with the assumptions of multinomial logistic regression (i.e. sample, outliers, etc.) and provide a good fit of the data. Those models are based on the following equation:

$\log \left(\frac{P(y=m \mid x)}{P(y=b \mid x)}=\beta_{m / b} x+\varepsilon \gamma \iota \alpha m=1, \ldots, j\right.$

where $\mathrm{b}$ is the baseline category, $\mathrm{m}$ are the occupational categories, $\mathrm{x}$ are the predicting variables кal $\varepsilon$ is the error term. The respective probabilities are computed as follows:

$P(y=m \mid x)=\frac{\exp \left(\beta_{m / b} x\right)}{\sum_{j=1}^{J} \exp \left(\beta_{j / b}\right)}$ 
A basic problem arising when running multinomial logistic regression is the independence of irrelevant alternatives hypothesis. The basic idea is that the choice of one level instead of another is not affected by the presence of alternative choices or levels (Hilbe, 2009). A method employed to test the IIA hypothesis is the Hausman specification test within which the null hypothesis is that there are no systematic differences in the estimators of the multinomial model (Long \& Freese, 2006). This test indicates no violation of the IIA hypothesis by the multinomial regression technique implemented in the analysis.

Thus, the next step in the analysis is to run the multinomial logit models to get another estimation of the strength of the relationship among father's and son's occupation before and after the statistical control of education. Figure 1 depicts the relative risk ratios of sons from low social status families to occupy higher skilled non-manual position in the occupational ladder as compared to sons from higher social status families to occupy same position. The empirical findings suggest that father's occupation is statistically significantly associated with sons' occupation in all welfare regimes. However, the extent of intergenerational persistence in occupations differs across the four welfare regimes in the EU. In other words, both before and after the statistical control of education, the analysis reveals that the intergenerational persistence in occupation is highest in the countries of the Liberal welfare regime and lowest in those of the Social-democratic one, whereas the countries belonging to the South-European and the Conservative-Corporatist welfare cluster occupy in-between positions.

\section{Figure 2: Relative risk ratios of intergenerational occupational persistence in the EU}

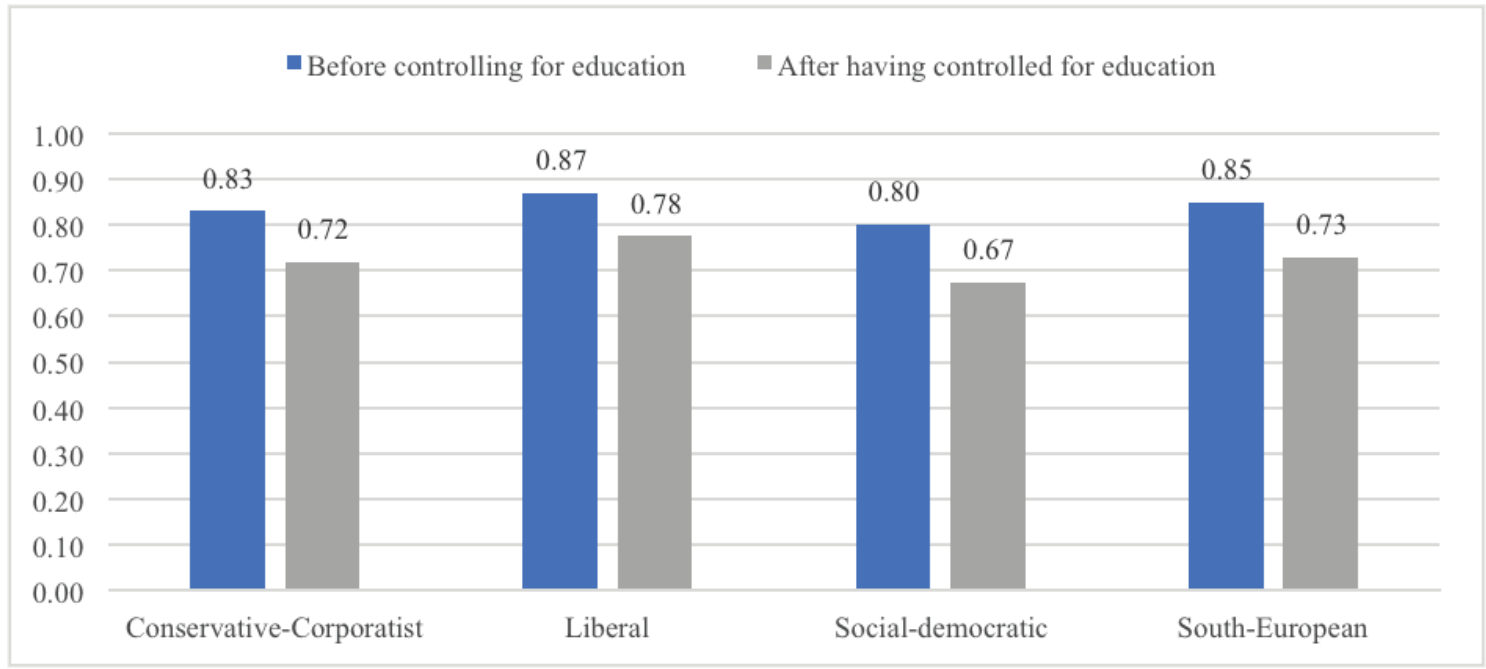

Note: The analysis includes rescaled clusters, weighted relative risk ratios, country/cohort fixed effects and education as individual covariate. The results are statistically significant at 0.05 level.

Source: Elaboration of microdata from EU-SILC 2005 UDB. 
Thus, the empirical findings indicate that the countries of the Social-democratic welfare regime are the most successful in mitigating the intergenerational occupational persistence. This can be attributed to the main policy components characterizing the social protection systems of those countries, that is, universal and still generous provisions in cash and in kind alongside friendly policies for families with children (Nolan et al, 2010). By contrast, the countries of the Liberal welfare regime exhibit the highest intergenerational persistence in the occupational attainments especially for the younger generations. This can mainly be explained by the wide restructuring of the welfare state that took place in those countries during the ' 80 s and the ' 90 s resulting in large cuts in social spending. Finally, the countries of the SouthEuropean and the Conservative-Corporatist welfare cluster place themselves in between based on the extent of intergenerational occupational persistence for various and slightly convergent reasons (e.g. the reliance on familism due to gaps or inequalities in social protection).

The final step in the analysis involves considering the correlation of fathers' and sons' occupations among the four EU welfare regimes. For this purpose, the same multinomial regression technique is implemented as described in Equation 1. The new element is the incorporation of interaction terms between the welfare clusters and fathers' occupation. The multinomial model yields statistically significant coefficient only for the interaction between the Social-democratic welfare cluster and fathers' occupation (Table 2). In contrast, there appear to be no statistically significant differences in the intergenerational correlation in occupations among the Conservative-Corporatist welfare cluster and the Liberal one as compared to the South-European welfare cluster.

\section{Conclusions}

By analysing the EU-SILC 2005 microdata through multinomial logit models, this paper provides insights for the performance of different social protection systems in mitigating the intergenerational persistence in occupations across the EU-14. The intergenerational persistence of the occupational status is lowest in the countries of the Social-democratic welfare regime, in-between in the countries of the Conservative and the South-European regime and highest in the countries of the Liberal regime.

The above findings imply that different institutional settings exert differing impact on the relationship between family of origin and individual occupational achievements. The countries representing the Social-democratic welfare regime have managed to substantially mitigate the path dependency in occupational trajectories across generations implying the effectiveness of the respective regulatory and redistributive institutions in promoting intergenerational occupational mobility. Therefore, more in-depth studies of the impact of different welfare state institutions on intergenerational occupational mobility may be of added value both to social researchers and policymakers. 
Table 2: Intergenerational occupational persistence among the EU welfare regimes

\begin{tabular}{|c|c|c|}
\hline Son's occupation & Coefficient & Robust std. error \\
\hline Skilled/unskilled manual (father) & $-1.85^{* * *}$ & 0.01 \\
\hline Lower skilled non-manual (father) & $-0.81^{* * *}$ & 0.04 \\
\hline Social-democratic & $0.18^{* * *}$ & 0.06 \\
\hline Liberal & -0.04 & 0.06 \\
\hline Conservative-Corporatist & $0.11^{* *}$ & 0.06 \\
\hline $\begin{array}{c}\text { Skilled/unskilled manual (father) } \mathrm{s} \\
\text { Social-democratic }\end{array}$ & $-0.28^{* * *}$ & 0.08 \\
\hline $\begin{array}{c}\text { Lower skilled non-manual (father) } \mathrm{x} \\
\text { Social-democratic }\end{array}$ & -0.05 & 0.11 \\
\hline $\begin{array}{c}\text { Skilled/unskilled manual (father) } \mathrm{x} \\
\text { Liberal }\end{array}$ & 0.08 & 0.13 \\
\hline $\begin{array}{c}\text { Lower skilled non-manual (father) } \mathrm{x} \\
\text { Liberal }\end{array}$ & 0.16 & 0.16 \\
\hline $\begin{array}{c}\text { Skilled/unskilled manual (father) } \mathrm{x} \\
\text { Conservative-Corporatist }\end{array}$ & -0.11 & 0.15 \\
\hline $\begin{array}{c}\text { Lower skilled non-manual (father) } \mathrm{x} \\
\text { Conservative-Corporatist }\end{array}$ & -0.15 & 0.09 \\
\hline $\mathrm{N}$ & 40774 & \\
\hline
\end{tabular}

Note: The analysis includes rescaled clusters, weighted coefficients and country/cohort fixed effects. Reference categories are: South-European welfare regime and higher skilled non-manual occupation (father).

Source: Elaboration of microdata from EU-SILC 2005 UDB.

From a policy perspective, a major response to the new social risks has been the transition from welfare to workfare. This entails the individual activation by means of human capital policies to get better access in the flexible labor market. However, this development signifies a process of recommodification of the status of the individuals vis-à-vis the market. The social investment approach is the main EU strategy against poverty-related problems and is explicitly designed to promote the employability of individuals. In consequence, an implicit individualization of social protection is underway leading to wide desocialization and depoliticization of social problems throughout the EU. 


\section{References}

Banerjee, A. \& Newman, A., (1993), "Occupational choice and the process of development", Journal of Political Economy, Vol. 101, pp. 274-298.

Becker, G. \& Tomes, N., (1979), "An equilibrium theory of the distribution of income and intergenerational mobility", Journal of Political Economy, Vol. 87, pp. 1153-1189.

Becker, G. \& Tomes, N., (1986), "Human capital and the rise and fall of families", Journal of Labour Economics, Vol. 4, pp. 1-39.

Boggess, S. \& Corcoran, M., (1999), “Cycles of disadvantage?”, In Boggess S, Corcoran M \& Jenkins S (Eds.): Cycles of disadvantage?, Wellington: Institute of Policy Studies.

Bowles, S. \& Gintis, H., (2002), “The inheritance of inequality”, Journal of Economic Perspectives, Vol. 16 (3), pp. 3-30.

Breen, R., \& Goldthorpe, J., (1999), "Class inequality and meritocracy: A critique of Saunders and an alternative analysis", British Journal of Sociology, Vol. 50, pp. 1-27.

Breen, R., \& Goldthorpe, J., (2001), Class, mobility and merit: The experience of two British birth cohorts, European Sociological Review, Vol. 17, pp. 81-101.

Causa, O., Dantan, S. \& Johanson, A., (2009), "Intergenerational social mobility in European OECD countries", OECD Working Paper No 50, Paris: OECD.

Carneiro, P. \& Heckman, J., (2003), "Human capital policy”, NBER Working Paper 9495, Cambridge: National Bureau of Economic Research.

Corcoran, M., (1995), "Rags to rags: Poverty and mobility in the United States", Annual Review of Sociology, Vol. 21, pp. 237-267.

Corcoran, M. \& Adams, T., (1997), "Race, sex and the intergenerational transmission of poverty”, In Duncan, G. \& Brooks-Gunn, J. (Eds.): Consequences of growing up poor, New York: Russell Sage Foundation, pp. 461-517.

d' Addio, A., (2007), "Intergenerational transmission of disadvantage: Mobility or immobility across generations? A review of the evidence for OECD countries", OECD Social, Employment and Migration Working Papers No. 52, Paris: OECD.

Durlauf, S., (2006), "Group, social influences and inequality: A membership theory perspective on poverty traps”, In Bowles, S., Durlauf, S. \& Hoff, K. (Eds.): Poverty traps, Princeton: Princeton University Press.

Eckstein, Z. \& Zilcha, I., (1994), “The effects of compulsory schooling on growth, income distribution and welfare", Journal of Public Economics, Vol. 54, pp. 339-359.

Erikson, R. \& Goldthorpe, J., (2002), "Intergenerational inequality: A sociological perspective”, Journal of Economic Perspectives, Vol. 16 (3), pp. 31-44.

Esping-Andersen, G., (1990), The three worlds of welfare capitalism, Oxford: Policy Press.

Esping-Andersen, G., (2004), "Untying the Gordian knot of social inheritance", Research in Social Stratification and Mobility, Vol. 21, pp. 115-139.

Ferrera, M., (2000), "Restructuring the welfare state in Southern Europe", In Kuhnle S (Ed): Survival of the European welfare state, London: Routledge, pp. 131-155.

Fisher, C., Hout, M., Jankowski, M., Lucas, S., Swidler, A., \& Voss, K., (1996), Inequality by design: Cracking the bell curve myth, Princeton, NJ: Princeton University Press. 
Fujita, M., Krugman, P. \& Venables, A. (1999), The spatial economy: Cities, regions, and international trade, Cambridge, MA: MIT Press.

Galor, O. \& Zeira, J., (1993), "Income distribution and macroeconomics", Review of Economic Studies, Vol. 60, pp. 35-52.

Goldthorpe, J., (2012), Understanding - and misunderstanding - social mobility in Britain: The entry of the economists, the confusion of politicians and the limits of educational policy, Oxford: Oxford University.

Haveman, R., Wolfe, B. \& Spalding, J., (1991), “Childhood events and circumstances influencing high school completion”, Demography, Vol. 28, pp. 133-157.

Heckman, J. \& Rubinstein, Y., (2001), “The importance of non-cognitive skills: Lessons from the GED testing program", American Economic Review, Vol. 91 (2), pp. 145-149.

Heckman, J., Stixrud, J. \& Urzua, S., (2006), "The effects of cognitive and non-cognitive abilities on labor market outcomes and social behavior", Journal of Labor Economics, 2006, Vol. 24, pp. 411-482.

Herrnstein, R. \& Murray, C., (1994), The bell curve: Intelligence and class structure in American life, New York: Free Press.

Hilbe, J., (2009), Logistic regression models, New York: CRC Press.

Krugman, P., (1991), "Increasing returns and economic geography", Journal of Political Economy, Vol. 99, pp. 483-499.

Leibfried, S., (1993), "Towards a European welfare state? On integrating poverty regimes into the European Community”, In Jones, C. (Ed.): New perspectives on the welfare state in Europe, London \& New York: Routledge.

Lewis, O., (1965), La Vida: a Puerto Rican family in the culture of poverty, New York: Random House.

Lewis, O., (1969), “The culture of poverty", In Moynihan, D. (Ed): On understanding poverty, New York: Basic Books, pp. 187-200.

Long, J. \& Ferrie, J., (2006), “A tale of two labour markets: Intergenerational occupational mobility in Britain and the U.S. since 1850", NBER Working Paper No. 11253.

Long, J. S. \& Freese, J., (2006), Regression models for categorical dependent variables using STATA, Stata Press: Texas.

Loury, G., (1981), "Intergenerational transfers and the distribution of earnings", Econometrica, Vol. 49, pp. 843-867.

Maitre, B. \& Whelan, C., (2008), General data quality issues in the EU-SILC 2005 intergenerational module, Dublin: EQUALSOC.

Mayer, S., (1997), What money can't buy: Family income and children's life chances, Cambridge: Harvard University Press.

Mazumder, B., (2001), Earnings mobility in the US: A new look at intergenerational inequality, Department of Economics, University of California at Berkeley.

Mazumder, B., (2005), "Fortunate sons: New estimates of intergenerational mobility in the US using social security earnings data", Review of Economics and Statistics, Vol. 87 (2), pp. 235-255. Mead, L., (1986), Beyond entitlement: The social obligations of citizenship, New York: Free Press. 
Mead, L., (1992), The new politics of poverty: The nonworking poor in America, New York City: Harper Collins.

Mookherjee, D. \& Ray, D., (2003), "Persistent inequality", Review of Economic Studies, Vol. 70, pp. 369-93.

Murray, C., (1984), Losing ground: American social policy, 1950-1980, New York: Basic Books.

Nolan, B., Esping-Andersen, G., Whelan, C., Maitre, B. \& Wagner, S., (2011), "The role of social institutions in intergenerational mobility”, In Erikson R., Jantti, M. \& Smeeding, T. (Eds.): Intergenerational mobility within and across nations, New York: Russell Sage.

Papanastasiou, S., Papatheodorou, C. \& Petmesidou, M., (2016), "Child poverty and intergenerational poverty transmission in the EU: What is the impact of social protection policies and institutions?", In Petmesidou, M., Delamonica, E., Papatheodorou, C. and Aldrie, H-L. (eds): Child poverty, youth (un) employment and social inclusion, CROP International poverty studies, Vol. 1, Stuttgart: CROP/Ibidem, pp. 67-89.

Papanastasiou, S. \& Papatheodorou, C., (2010), Intergenerational transmission of poverty in the EU: An empirical analysis, Paper presented at the $1^{\text {st }}$ IIPPE, Crete: Rethymno.

Papatheodorou, C \& Papanastasiou S (2010), Intergenerational poverty transmission and social protection in the EU: Theoretical and empirical analysis, Athens: INE/GSEE.

Saunders, P., (1996), Unequal but fair? A study of class barriers in Britain, London: IEA.

Saunders, P., (1997), "Social mobility in Britain: An empirical evaluation of two competing theories", Sociology, Vol. 31, pp. 261-288.

Saunders, P, (2002), "Reflections on the meritocracy debate in Britain: A response to Richard Breen and John Goldthorpe", British Journal of Sociology, Vol. 53, pp. 559-574.

Shelling, T., (1971), "Dynamic models of segregation", Journal of Mathematical Sociology, Vol. 1 , pp. 143-186.

Strenze, T., (2007), "Intelligence and socioeconomic success: A meta-analytic review of longitudinal research”, Intelligence, Vol. 35, pp. 401-426.

Torche, F, (2013), How do we characteristically measure and analyze intergenerational mobility?, New York: Stanford Center on Poverty and Inequality. 